\title{
Pesticide load reducing in vineyard protection from powdery mildew
}

\author{
Natalia Arestova ${ }^{1,}{ }^{*}$ and Irina Ryabchun $^{1}$ \\ ${ }^{1}$ All-Russian Research Institute named after Ya.I. Potapenko for Viticulture and Winemaking, 346421 \\ Novocherkassk, Russia
}

\begin{abstract}
The results of studies on the possibility of applying the biological product Bacillus subtilis for the protection of vineyards from powdery mildew are presented. Meteorological conditions in 2016 and 2018 contributed to the epiphytotic prevalence of powdery mildew in the agrocenosis of Rostov region. In 2015, 2017 and 2019 its prevalence was moderate. The use of biological preparation against powdery mildew showed the prospects of its application. With a moderate degree of disease prevalence, the use of a biological preparation instead of chemical fungicides is possible in all phases of a growing season. It inhibits the pathogen's development, contributes to conservation of plants' productivity and reducing the pesticide load. In years with epiphytotic prevalence of powdery mildew it is desirable to apply fungicides during pre-veraison, and biopreparation - up to the phase of technical maturity. Such application will contribute to obtaining a quantitative and qualitative yield, and will also reduce the toxicological effect of chemical fungicides used in the first half of a growing season.
\end{abstract}

\section{Introduction}

Powdery mildew is fungal disease caused by the pathogen Uncinula necator. The researchers note that the disease appeared in the United States. It was introduced to Europe in the mid19 th century and spread very quickly, causing significant economic damage to the industry $[1,2]$. Until the 90 s of the 20th century, the prevalence of powdery mildew in Don vineyards was very weak and spotty, and protective measures were not carried out. The increase in the harmfulness of powdery mildew occurred in the 90s.

All green organs of a vine are infected by powdery mildew: shoots, leaves, inflorescences and immature berries [3].

Having a wide spread and high aggressiveness, powdery mildew is a big problem for winegrowers in many countries [4]. According to the researchers, yield reduction reaches up to $50-60 \%$, and in the years of epiphytoties it increases up to $80 \%$ or even more.

The disease cycle of this fungus consists of two stages - primary infection with an inoculum, which is a mycelium and ascospores released by kleistotecium. Primary infections can occur as a result of overwintering of mycelium in the buds of vines or from ascospores produced by chasmotecia. In the early stages of development in late summer, they are white.

\footnotetext{
*Corresponding author: zash.arestova@yandex.ru
} 
As they mature morphologically, they turn black. At this stage, the chasmothecia lose its connection witn mycelium and can be dispersed by rain and wind to a vine and soil. The release of ascospores always begins after budding and usually ends before flowering. Periods of ascospore release are associated with precipitation exceeding $2 \mathrm{~mm}$, moisture duration exceeding 2.5 hours, average temperature exceeding $11^{\circ} \mathrm{C}$, and the sum of the average daily temperatures during the dormant period before the first ascospore release above $1100^{\circ} \mathrm{C}$. The temperature thresholds for ascosporic infection are $5{ }^{\circ} \mathrm{C}$ and $31^{\circ} \mathrm{C}$. The fastest colony growth and sporulation occurs at temperatures from $23^{\circ} \mathrm{C}$ to $30^{\circ} \mathrm{C}[5,6]$.

The speed of wind is of great importance in the pathogen's spread. The wind causes the rapid spread of E. necator conidia. The minimum wind speed for its spread is $2.3 \mathrm{~m} / \mathrm{s}$ [7].

Most V. vinifera grapevine varieties are pathogen-resistant. One of the ways to reduce the economic damage caused to vineyards is to breed varieties that are resistant or tolerant to the disease. Species Vitis spp. is more resistant to the disease, but the North American varieties cannot be characterized by a high quality grapes. Through the efforts of scientists, donors and sources of resistance to powdery mildew were obtained with sufficiently high quality characteristics [8-10].

An important component in the fight against powdery mildew is the optimization of agricultural technologies of cultivation. Various methods of vine pruning, which provide free air exchange in the cluster area, as well as the removal of leaves, can significantly reduce the moisture content of the leaves, thereby suppressing the development of the disease [11].

The use of fungicides is the main method of controlling powdery mildew. According to the report on the use of grapevine protection products in the European Union, the area under vineyards in Europe occupies $3.3 \%$ of all agricultural crops, while the percentage of fungicides used in the vineyard is $67 \%$, which leads to significant environmental pollution and an increase in the cost of grapevine production [12].

In practical viticulture, both organic and inorganic fungicides are used in the fight against Uncinula necator. Until recently, sulfur, an inexpensive and effective fungicide, was widely used all over the world. Fungicides that include benzimidazoles, inhibitors of ergosterol biosynthesis, are also widely used. With repeated use of these drugs, the pathogen develops resistance. Therefore, it is necessary to select protective means very carefully.

Biological control of the disease development is quite limited due to insufficient effectiveness against the pathogen. The strains of the fungi Ampelomyces quisqualis, Trichoderma afroharzianum are a bit effective in suppressing the disease [13, 14].

The most effective is the use of combined protection systems aimed at reducing the pesticide load, including the use of environmentally safe preparations and permitted pesticides. The best method is to carry out the main pesticide treatments during the first half of the growing season, and during the second half to apply biological preparations only. This contribute to the reduction of pesticide residues in products, and improves the quality of grapes and wine [15].

Our studies have shown that the effectiveness of the most active microbiological preparations can be $67 \%$, which is not enough for economically expedient grape production [16].

In this regard, there was a need to improve the system of protection against powdery mildew, including the use of both chemical and biological means of protection, that was research objective. We conducted the study in 2015-2019 to determine the biological and economic effectiveness of the use of combined multivariate schemes for protecting grapevine plants from powdery mildew, taking into account the specificities of their development in this agro-climatic zone.

\section{Materials and methods}


The research was carried out in Rostov region on mycosis-susceptible plantings of wine Cabernet Sauvignon variety cultivated with agrotechnical measures recommended for this zone. In the field conditions, the biological and economic efficiency of applying a biological preparation with the active substance - the soil bacterium Bacillus subtilis strain B-10 with a titer of at least $10^{11} \mathrm{cfu} / \mathrm{g}$ and a consumption rate of 40-100 $\mathrm{g} / \mathrm{ha}$ against powdery mildew was studied. The effect of the biological product on the growth and development of grapevine plants was evaluated by the main biological indicators that characterize the vegetative (the average shoot length and its mature part) and generative (the quantity and quality of the crop) development of bushes.

The assessment of the degree of damage by powdery mildew was carried out on a fivepoint scale:

0 points - no visible signs of damage;

1 point - single small foci of weak development of the fungus;

2 points - the foci are larger, the development of the fungus increases;

3 points - non-merging large foci, intensive development of the fungus;

4 points - large merging spots with intensive development of an actively spore-bearing fungus;

5 points - a solid infection, there is a dense white-gray coating.

The fungicides used in the experiment had different active substances: Penconazole is a systemic drug of the triazole chemical group, Metrafenone is a preventive fungicide of the benzophenone class. Penconazol (100g/l), consumption rate 0.4 1/ha; Metrafenone (500 g/l), consumption rate $0.2-0.25 \mathrm{l} / \mathrm{ha}$; Sulfur $(80 \mathrm{~g} / \mathrm{kg})$, consumption rate $5-8 \mathrm{~kg} / \mathrm{ha}$; the biological preparation with the active substance Bacillus subtilis strain b-10 (titer not less than $\left.10^{11} \mathrm{cfu} / \mathrm{g}\right)$, the rate of $40-100 \mathrm{~g} / \mathrm{ha}$. In the research, the experimental variants were compared with reference and control (without treatment). The reference was the variant with the sulfur preparation, the control - without any treatment (Table 1).

The intensity of plant disease damage was evaluated on the 7 th day after treatment and before the next spraying according to the experimental variants.

Table 1. Scheme of protective treatments against powdery mildew in the phases of vegetation

\begin{tabular}{|c|c|c|c|c|l|}
\hline \multirow{2}{*}{ Variant } & \multicolumn{5}{|c|}{ Treatment of vine in the vegetation phases } \\
\cline { 2 - 6 } & $\begin{array}{c}\text { bloom } \\
\text { beginning }\end{array}$ & post-bloom & $\begin{array}{c}\text { berry } \\
\text { growth }\end{array}$ & $\begin{array}{c}\text { beginning of } \\
\text { berry } \\
\text { coloring }\end{array}$ & $\begin{array}{c}\text { berry } \\
\text { maturation }\end{array}$ \\
\hline 1 & Penconazole & Metrafenone & Penconazole & Metrafenone & - \\
\hline 2 & $\begin{array}{l}\text { biopreparat } \\
\text { ion }\end{array}$ & biopreparation & $\begin{array}{l}\text { bioprepara } \\
\text { tion }\end{array}$ & $\begin{array}{l}\text { biopreparatio } \\
\text { n }\end{array}$ & $\begin{array}{l}\text { biopreparation } \\
\text { (2 rounds) }\end{array}$ \\
\hline 3 & Penconazole & Metrafenone & Penconazole & Metrafenone & $\begin{array}{l}\text { biopreparation } \\
\text { (2 rounds) }\end{array}$ \\
\hline 4 & Penconazole & Metrafenone & Penconazole & Metrafenone & Sulfur (2 rounds) \\
\hline 5 & Sulfur & Sulfur & Sulfur & Sulfur & $\begin{array}{l}\text { Sulfur } \\
\text { (2 rounds) }\end{array}$ \\
\hline
\end{tabular}

\section{Results and Discussion}

An important role in the occurrence of diseases, the way of their spread and development is played by abiotic elements of environment - climate, meteorological conditions. They are the dominant factor, influencing annual variation in development of harmful organisms.

Meteorological conditions during the growing season of the last five years of observations (2015-2019) generally contributed to the moderate prevalence of powdery mildew, with the exception of 2016 and 2018, with the epiphytotic development of the phytopathogen. The 
limiting factors contributing to pathogen depression were: insufficient precipitation, low humidity, and high air temperatures (fig. 1).

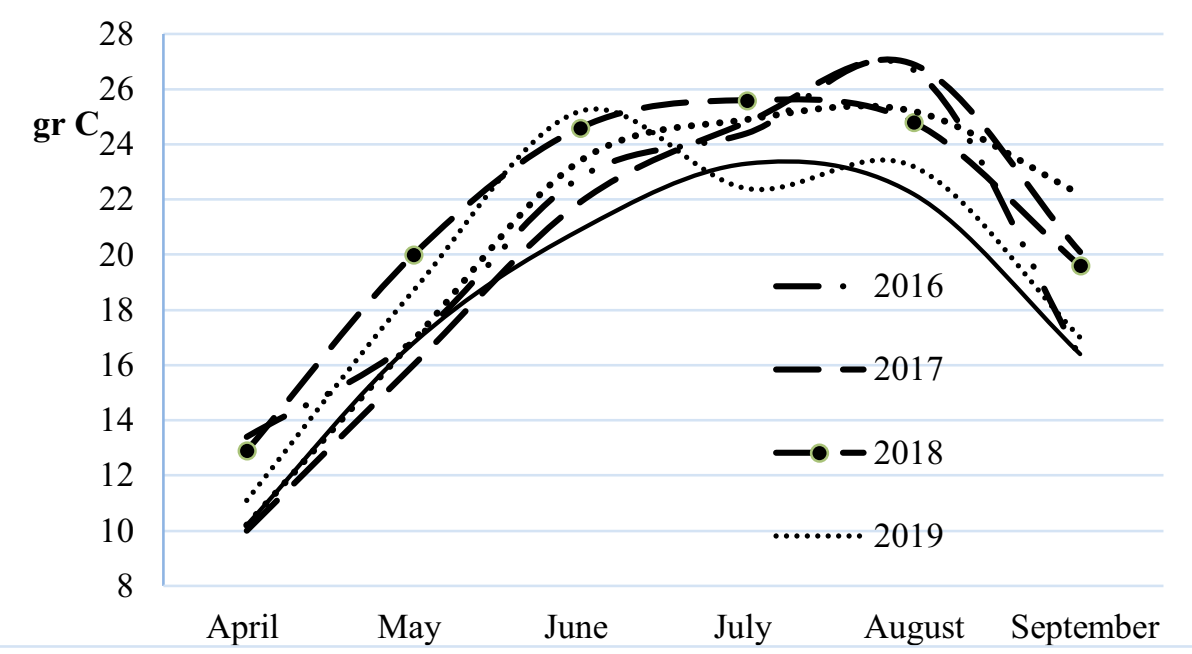

Fig. 1. The course of temperatures in the growing season 2015-2019. Temperature range

Precipitation during the growing season fell unequally. In the spring months (April, May), precipitation was 0.7-13.3 times more than normal, with the exception in 2018, when its shortage was $82 \%$ (in April) and 52\% (in May), in the summer months, the shortage of precipitation, with the exception of July 2016 and 2018, was from $6 \%$ to $92 \%$. (fig. 2).

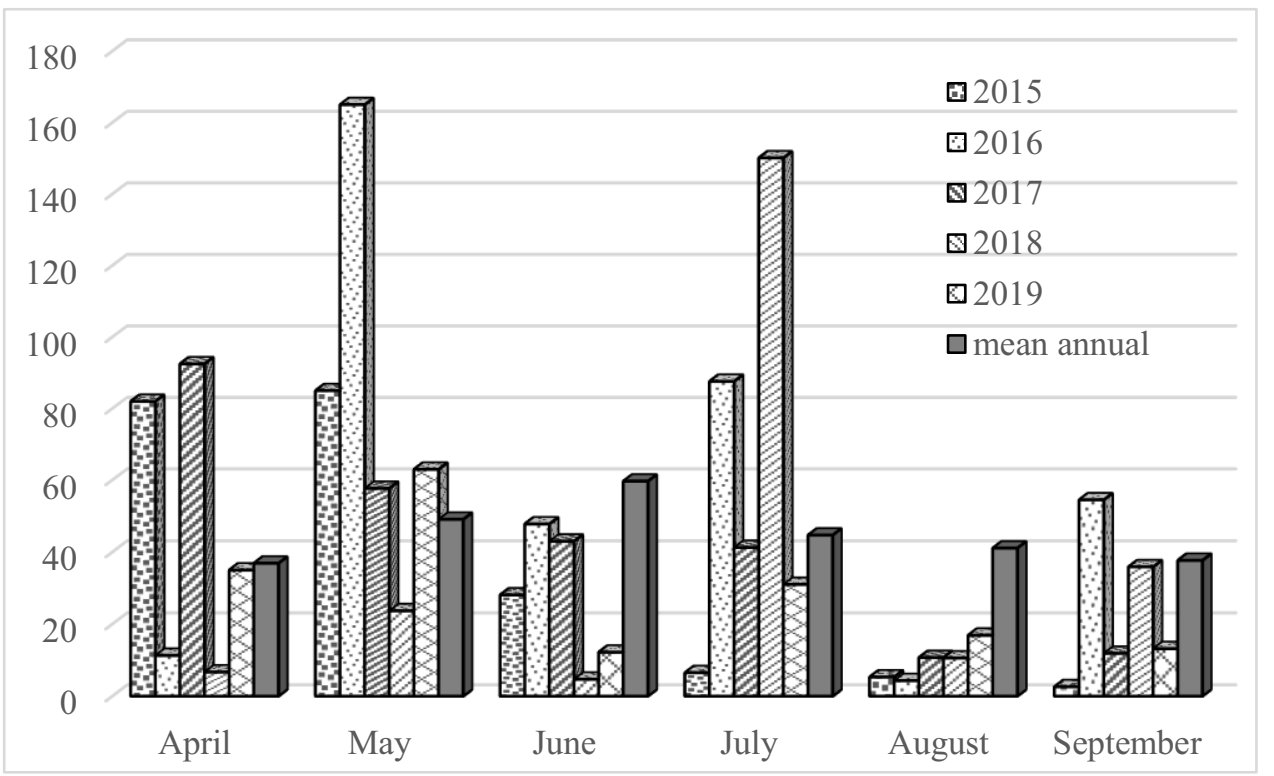

Fig. 2. Precipitation during the growing season 2015-2019

The hydrothermal coefficient (GTC), which shows the degree of moisture content of the territory and is average 0.7 for the Rostov region, varied by month - from 0.1 to 3.1, which indicates the alternation of dry and wet periods (Table 2).

Table 2. Hydrothermal coefficient, average for 2015-2019 


\begin{tabular}{|c|c|c|c|c|c|c|}
\hline \multirow{2}{*}{ Year } & \multicolumn{7}{|c|}{ Hydrothermal coefficient (GTC) } \\
\cline { 2 - 7 } & April & May & June & July & August & September \\
\hline 1 & 2 & 3 & 4 & 5 & 6 & 7 \\
\hline 2015 & 2.7 & 1.6 & 0.4 & 0.4 & 0.4 & 0.1 \\
\hline 2016 & 0.3 & 3.1 & 0.7 & 1.1 & 0.5 & 1.1 \\
\hline 2017 & 3.1 & 1.1 & 0.6 & 0.5 & 0.1 & 0.2 \\
\hline 2018 & 0.2 & 0.4 & 0.1 & 1.9 & 0.1 & 0.6 \\
\hline 2019 & 1.0 & 1.1 & 0.2 & 0.4 & 0.2 & 0.3 \\
\hline
\end{tabular}

The data in Table 3 shows that the highest amount of precipitation in the summer months and, accordingly, the highest hydrothermal coefficient, were observed in July 2016 and 2018. In the same years, under moderately hot weather and high humidity, contributing to the development of powdery mildew, epiphytotic development of the pathogen was observed, especially in the second half of the growing season, when the intensity of plant damage exceeded 3.5 points (Table 3 ).

Table 3. Intensity of powdery mildew prelevance (points) in 2015-2019 on the natural spread of the disease, Cabernet Sauvignon variety

\begin{tabular}{|l|l|l|l|l|l|}
\hline Vegetative phase & $\mathbf{2 0 1 5}$ & $\mathbf{2 0 1 6}$ & $\mathbf{2 0 1 7}$ & $\mathbf{2 0 1 8}$ & $\mathbf{2 0 1 9}$ \\
\hline Pre-bloom & 0 & 0 & 0 & 0 & 0 \\
\hline Post-bloom & 0 & 0.5 & 0 & 0 & 0 \\
\hline Berry growth & 0.9 & 2.5 & 1.0 & 1.8 & 0.5 \\
\hline Berry coloring & 1.9 & 3.7 & 1.7 & 3.6 & 2.1 \\
\hline Berry maturation & 2.8 & 4.8 & 2.5 & 4.3 & 2.9 \\
\hline
\end{tabular}

Plant damage by powdery mildew in 2015, 2017 and 2019 was moderate.

Our study indicate that the use of the biological preparation as a fungicide have biological effectiveness exceeding the control variant in all years of research, regardless of the intensity of powdery mildew prelevance. In the years with epiphytotic development of powdery mildew $(2016,2018)$, variant 3 showed the best effectiveness with the use of chemical fungicides at the beginning of the growing season and a biological product - in variant, when chemical preparations cannot be used due to its toxicity. In the years of moderate development of powdery mildew, the fungicidal activity of the biological product was at or above the reference variant with the use of sulfur (fig. 3).

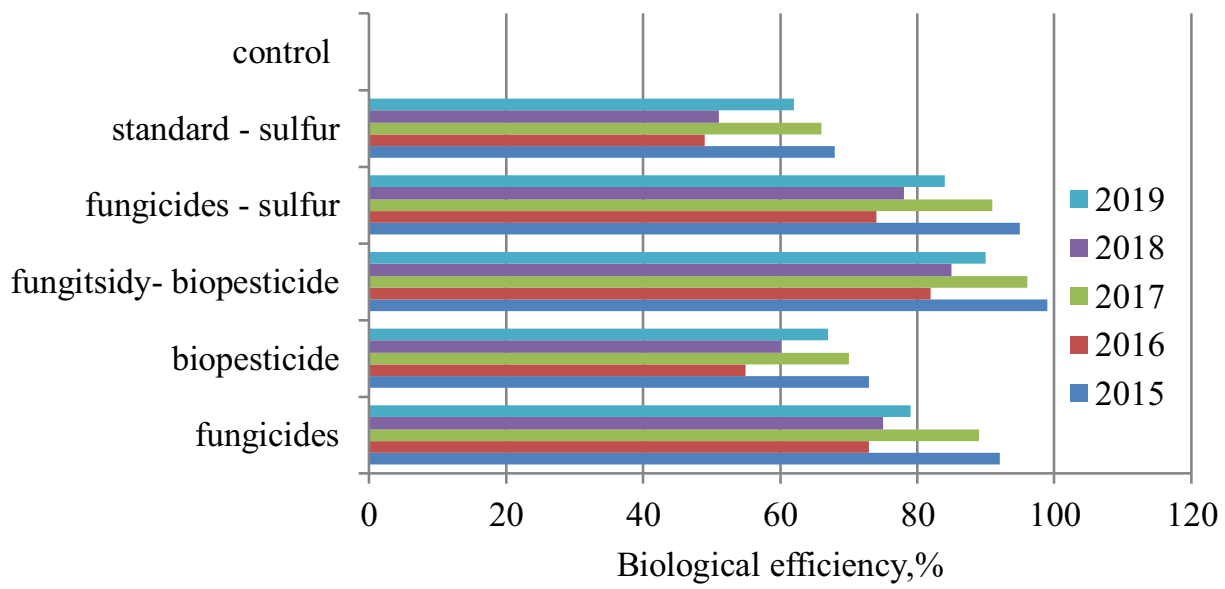


Fig.3. Biological effectiveness of the biological preparation in comparison with the control and experimental variants, Cabernet Sauvignon variety

The use of the biological preparation had a positive effect on grapevine productivity, which resulted in a significant yield increase compared to the control (fig. 4).

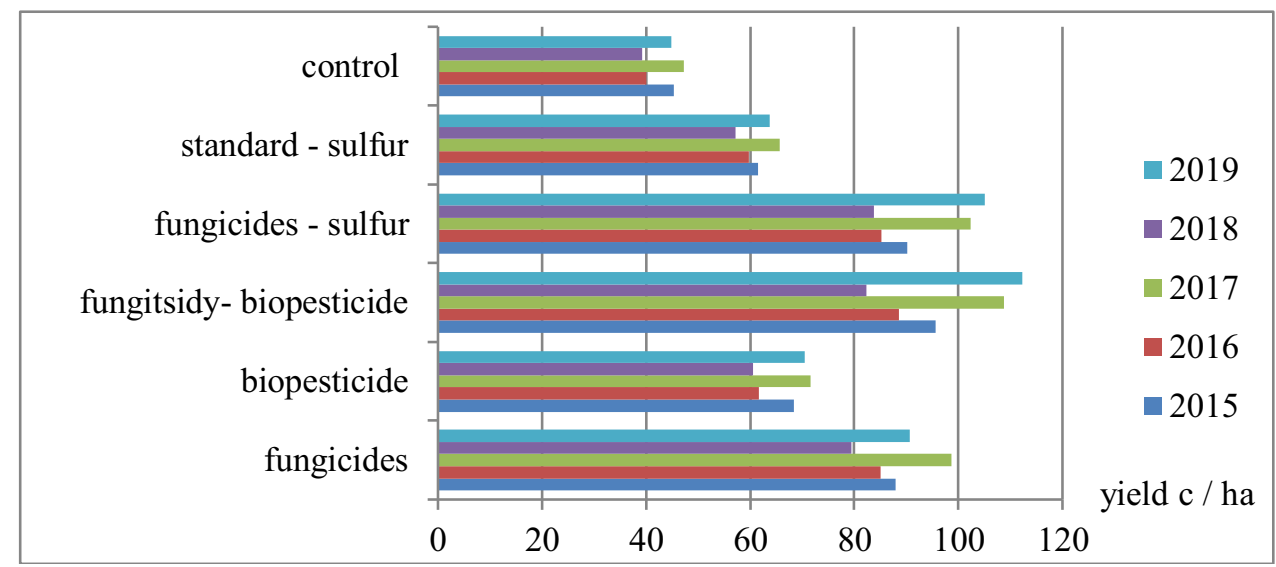

Fig.4. Grapevine yield depending on the applied fungicides, Cabernet Sauvignon variety

Crop yields in variant 2 with the use of biological preparation has been at or slightly higher than the reference variant, but was significantly lower than in the variants with fungicide $(3,4)$, and significant differences increased in the years of epiphytotic of powdery mildew.

The qualitative indicators of the yield (mass concentration of sugars and titrated acids) in the variant with the use of the biological preparation (2) were significantly higher than in the control and reference variants (Table 5)

Table 5. Effect of the biological preparation on crop quality indicators, Cabernet Sauvignon

\begin{tabular}{|c|c|c|c|c|c|c|c|c|c|c|}
\hline \multirow[t]{3}{*}{ Treatment } & \multicolumn{10}{|c|}{ Mass concentration } \\
\hline & \multicolumn{5}{|c|}{ sugars, $\Gamma / 100 \mathrm{sm}^{3}$} & \multicolumn{5}{|c|}{ titratable acids, $\mathrm{g} / \mathrm{dm}^{3}$} \\
\hline & 2015 & 2016 & 2017 & 2018 & 2019 & 2015 & 2016 & 2017 & 2018 & 2019 \\
\hline $\begin{array}{l}\text { 1-Fungicides } \\
\text { rounds) }\end{array}$ & 21.8 & 21.2 & $\begin{array}{c}22 . \\
7\end{array}$ & 20.4 & 22.1 & 8.1 & 8.9 & 8.4 & 9.1 & 8.7 \\
\hline $\begin{array}{l}2-\quad \text { Biological } \\
\text { preparation } \\
\text { (6 rounds) }\end{array}$ & 23.6 & 22.5 & $\begin{array}{c}23 . \\
3\end{array}$ & 22.4 & 23.0 & 7.1 & 7.5 & 6.9 & 7.3 & 6.9 \\
\hline $\begin{array}{l}\text { 3- Fungicides ( } 4 \\
\text { times)- biological } \\
\text { preparation } \\
\text { ( } 2 \text { rounds) }\end{array}$ & 22.6 & 22.0 & $\begin{array}{c}22 . \\
8\end{array}$ & 21.9 & 22.5 & 7.5 & 8.1 & 7.3 & 8.4 & 7.5 \\
\hline $\begin{array}{l}\text { 4- Fungicides (4 } \\
\text { times) - sulfur } \\
\text { ( } 2 \text { rounds) }\end{array}$ & 21.9 & 21.6 & $\begin{array}{c}22 . \\
3\end{array}$ & 20.9 & 21.9 & 7.9 & 8.5 & 7.9 & 8.6 & 7.3 \\
\hline $\begin{array}{l}\text { Reference -sulfur } \\
\text { ( } 6 \text { rounds) }\end{array}$ & 20.6 & 20.2 & $\begin{array}{c}21 . \\
9\end{array}$ & 19.9 & 21.3 & 8.3 & 8.9 & 7.5 & 9.0 & 8.2 \\
\hline $\begin{array}{l}\text { Control-without } \\
\text { treatments }\end{array}$ & 19.0 & 18.1 & $\begin{array}{c}19 . \\
0\end{array}$ & 17.5 & 19.7 & 9.7 & 10.6 & 9.5 & 10.3 & 9.5 \\
\hline $\mathrm{LSD}_{05}$ & 1.1 & 1.3 & 0.9 & 1.2 & 0.7 & 0.9 & 1.2 & 0.6 & 1.1 & 0.7 \\
\hline
\end{tabular}


Furthermore, in some years $(2015,2016,2018,2019)$ the use of biological preparations contributed to higher accumulation of sugars and lower of titratable acids compared to variant 1 (using only fungicides). We explain this fact due to deterioration of maturity because of the damage by powdery mildew, as a result of termination of the protective effect of chemical fungicides in the phase of maturity in the period of intensive development of powdery mildew in our environment.

Our studies revealed significant differences in growth activity only between the control and the other variants. The significance of the differences between the variants of the experiment for the annual vine growth has not been proven.

The significance of differences in the degree of vine maturation is proved for all variants of the experiment, compared with the control, as well as for the variants among themselves (fig. 5).

The vine maturation in the reference variant (5) was better than in the control one, but significantly worse than in the other variants. The best positive effect on vine maturation was in the variant with the use of fungicides (in the first half of the growing season) and the biological preparation (in the phase of berry ripening) (option 3). In the years of epiphytotic prevalence of powdery mildew $(2016,2018)$, the significance of differences in the degree of vine maturation between variants 3 and 4 has not been proven. In the years with moderate development of powdery mildew $(2015,2017)$, the significance of differences in vine maturation has not been proven for variants 1 (with the use of fungicides) and 2 (with the use of a biological preparation)

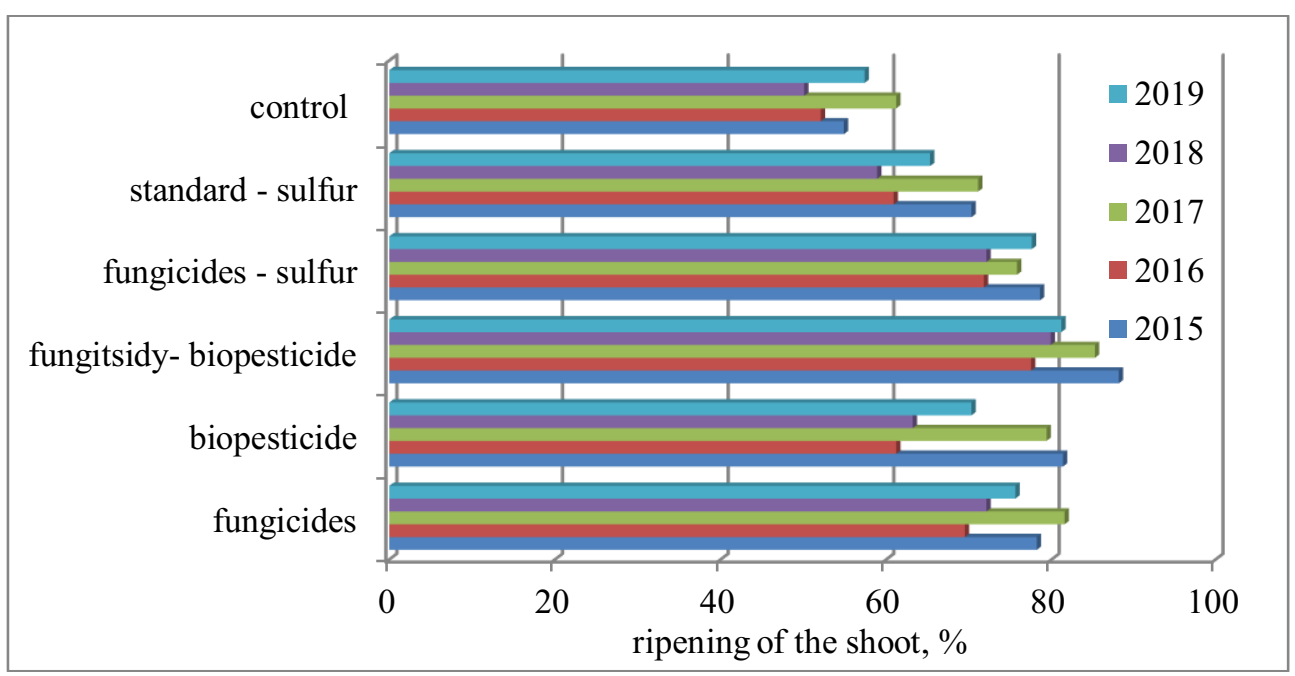

Fig. 3. Vine maturation of Cabernet Sauvignon variety depending on the experimental variants

\section{Conclusions}

The influence of weather conditions on the epiphytotic prevalence of the pathogen was revealed. The greatest amount of precipitation in the summer months of 2016 and 2018, with moderately hot weather and high humidity, contributed to the intensive development of powdery mildew (3.5 points). In the other years of the research, meteorological conditions contributed to the moderate prevalence of the disease.

In the years of epiphytotic spread of powdery mildew $(2016,2018)$ the most effective and safe was the complex use of chemical fungicides and biological preparation according to the scheme: in the first half of the growing season - the use of chemical drug, in the phase of 
maturity - the use of a biological preparation. With this protection scheme, the maximum yield was achieved, exceeding the standard by $30 \%$.

In the years of moderate prevalence of powdery mildew, the fungicidal activity of the biological preparation was at or above the reference -with the use of sulfur. The use of biological preparation allowed us to obtain a yield at or above the reference, but significantly lower than with the use of fungicides.

The use of the biological preparation contributed to a high-quality crop, as it is evidenced by the high sugar content and low titratable acids in a berry juice.

The use of fungicides and biological preparation had a positive effect on vine maturation, especially in the years of epiphytotic development of the pathogen.

Thus, the use of the biopreparation against the powdery mildew of grapevine is perspective in combination with chemical fungicides. In years with epiphytoties prevalence of powdery mildew, it is desirable to apply fungicides during the periods preceding veraison, and biopreparation - up to the phase of technical maturity. Such scheme will contribute to a quantitative and qualitative yield, and will reduce toxicological effect of the use of chemical fungicides in the first half of the growing season.

\section{References}

1. D.M. Gadoury, L. Cadle-Davidson, W.F. Wilcox, I.B. Dry, R.C. Seem, M.G. Milgroom, Mol Plant Pathol., 13(1), 1-16, (2012) doi: 10.1111/j.1364-3703.2011.00728.x. Epub 2011 Jun 20. PMID: 21726395; PMCID: PMC6638670.

2. B. Nakova, K. Nakov, M. Tityanov, BIO Web Conf. 9, 01021 (2017) DOI: 10.1051/bioconf/20170901021

3. M. Fernández-González, F. J. Rodríguez-Rajo, O. Escuredo, M.J. Aira, J. Agric. Sci., 151, 648-658 (2013) DOI: 10.1017/S0021859612000743

4. B. Bois, S. Zito, A. Calonnec, OENO One, 51, 133-139 (2017) https://doi.org/10.20870/oeno-one.2017.51.2.1780

5. E. González-Fernández, A. Piña-Rey, M. Fernández-González, F. J. Rodríguez-Rajo, Vitis, 58, 49-58 (2019) DOI: 10.5073/vitis.2019.58.special-issue.49-58

6. M. Redl, L. Sitavanc, B. Spangl, et al., J PlantDisProt (2020) https://doi.org/10.1007/s41348-020-00376-0

7. M. M. Moyer, D. Gadoury, W. Wilcox, R. Seem, American Journal of Enology and Viticulture, 65(3), 315 - 324 (2014) DOI:10.5344/ajev.2014.13111

8. L. Gaforio, S. Garcia-Muñoz, F. Cabello, G. Muñoz-Organero, Vitis, 50(3), 123-126 (2011)

9. A. Mwamahonje, D. Kilambo, L. Mrosso, T. Feyissa, Journal of Advancesin Agriculture, 5(1), 4509 (2015) DOI: 10.24297/jaa.v5i1.4509

10. H. Karbalaei Khiavi, A. Davoodi, J. Crop Prot. 5(2), 229-237 (2016) doi: 10.18869/modares.jcp.5.2.229

11. D. M. Gadoury, L. Cadle-Davidson, W. F. Wilcox, I. B. Dry, R. C. Seem, M. G. Milgroom, Molecular Plant Pathology, 13(1), 1-16 (2012) DOI: 10.1111/j.13643703.2011.00728.x

12. W. Qiu, A. Feechan, I. Dry, Hortic Res 2, 15020 (2015) https://doi.org/10.1038/hortres.2015.20 
13. I. S. Sawant, P.N. Wadkar, S. B. Ghule, Y. R. Rajguru, V. P. Salunkhe, S. D. Sawant, Biological Control, 114, https://doi.org/10.1016/j.biocontrol.2017.08.011.

14. S. Ghule, I. Sawant, S. Sawant, S. Saha, R. Devarumath, Australasian Plant Pathology, 48, 351-367 (2019) doi 48. 10.1007/s13313-019-00636-0.

15. I. Pertot, T. Caffi, V. Rossi, L. Mugnai, C. Hoffmann, M.S. Grando, et al. Crop Protection, 97, 70-84 (2017) https://doi.org/10.1016/j.cropro.2016.11.025

16. N.O. Arestova, I.O. Ryabchun, Scientific Works of North Caucasian Federal Scientific Center of Horticulture Viticulture Wine-making, 18, 86-90 (2018) DOI: 10.30679/25879847-2018-18-86-90 